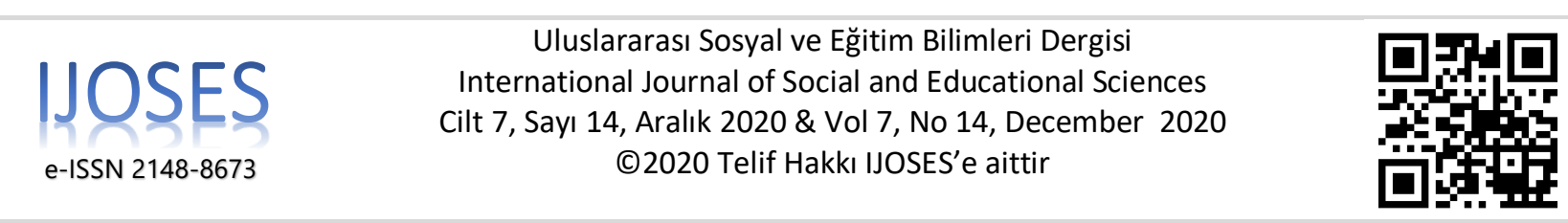

DOI: $10.20860 /$ ijoses. 822934

http://dergipark.gov.tr/ijoses

http://www.ijoses.com

Geliş Tarihi \& Received: 07.11.2020

Kabul Tarihi \& Accepted: 08.12.2020

IJOSES, 2020, 7(14): 175-194

\title{
Atatürk Dönemi Tarım Alanında Devletçilik Uygulamaları ve Antalya
}

State Practices in the Field of Agriculture in the Atatürk Period and Antalya

\section{Yüksel Kaştan*}

$\ddot{O} z$

Osmanlı Devleti'nin son dönemi ve Milli Mücadele Dönemi savaşlar nedeniyle geçmiştir. Savaşlarda hem kaybedilen topraklar hem de kaybedilen insan gücü tarım faaliyetlerini de etkilemiş ve devletin önemli gelir kayıplarına neden olmuştur. Osmanlı Devleti tarım alanında yurt dışına öğrenci göndermiş, yurt dışından yurtdışından uzmanlar getirmiş, makine getirmiş, okullar açmış ve bu şekilde tarım faaliyetlerini artırmayı amaçlamıştır. Türkiye Cumhuriyeti Atatürk Dönemi'nde de tarım alanında bu amaçlar aynen takip edilmiştir. Ancak halkın daha fazla toprağı işleyip fazla ürün alabilmesi için bir takım bilimsel ve yasal düzenlemeler yapmış, tarım alanında okulları yeniden düzenlemiş, halkın yapamayacağ 1 konularda numune çiftlikleri, tohum ıslah istasyonları, deneme tarlaları, tarım ürünlerini işleyecek fabrikalar, Kamu İktisadi Teşekküller kurmuştur. Böylece Atatürk Dönemi’nde devlet tarım alanında önemli kuruluşlar ile tarım alanında bilgilendirmiş, yaptığı ıslah çalışmaları, ürettiği tohumlar, üretme teknikleri ve makineli tarım şekli ile halkı bilgilendirmiş ve halka örnek olmuştur.

Bu çalışmada Atatürk Dönemi'nde tarım alanında devletçilik uygulamaları ve Antalya'da bu devletçilik uygulama örnekleri araştırılmıştır. Araştırma doküman analizi şeklinde yapılmış, elde edilen veriler analiz edilerek metin oluşturulmuştur.

Anahtar Kelimeler: Atatürk, dönem, devletçilik, tarım, uygulama, Antalya.

\begin{abstract}
The last period of the Ottoman Empire and the period of the National Struggle passed due to wars. Both the lands lost and the manpower lost during the wars also affected the agricultural activities and caused significant income losses of the state. The Ottoman Empire sent students abroad in the field of agriculture, brought experts from abroad, brought machinery, opened schools and aimed to increase agricultural activities in this way. In the field of agriculture in the Republic of Turkey, Atatürk period was followed exactly these purposes. However, he made a number of scientific and legal regulations in order for the people to cultivate more land and buy more crops, reorganized schools in the field of agriculture, established sample farms, seed breeding stations, trial fields, factories to process agricultural products, and State Economic Enterprises. Thus, in the Atatürk Period, the state informed the people in the field of agriculture with important organizations in the field of agriculture, informed the public with the breeding studies, the seeds it produced, the production techniques and the method of mechanized agriculture and became an example to the public.

In this study, statism practices in the field of agriculture in the Atatürk Period and examples of this statism in Antalya were investigated. The research was conducted in the form of document analysis, and the text was created by analyzing the obtained data.
\end{abstract}

Keywords: Atatürk, period, statism, agriculture, practice, Antalya.

* (Prof. Dr.); Akdeniz Üniversitesi, kastanyuksel@ hotmail.com, ORCID: 0000-0002-8616-8968

Kaynak Gösterme: Bardak, M . " Atatürk Dönemi Tarım Alanında Devletçilik Uygulamaları ve Antalya". Uluslararası Sosyal ve Eğitim Bilimleri Dergisi 7 (2020): 175-194. 


\section{Extended Summary}

In the introduction of this research, the state of the country in the last period of the Ottoman Empire in the last period, agricultural areas, arable land, agricultural machinery and tools used, cereals planted, legumes, cultivation areas of industrial plants and their production amounts are examined. Later, in the Agricultural Census in 1927, the area and production that were cultivated and planted in the country were emphasized.

The reforms in the field of agriculture in the last period of the state, laws enacted, schools established and sending students abroad are discussed in the part of the research in the field of agriculture in the Ottoman Empire. Later, the introduction of mechanized agriculture in the country and which agricultural products would be suitable in various parts of the country were discussed, reports prepared by experts brought from abroad.

Period of Atatürk's Reforms Working title in the Field of Agriculture, scientific and administrative activities in the field of agriculture in the country is regulated under the sub-heading I. Turkey Economy Congress, National Economy and Society Founded Savings were examined. Later, the 1st Agriculture Congress held in Ankara in 1931, the agricultural report published by scientists invited from Russia after their research, the reports prepared by German scientists in terms of fruit growing and plant species were discussed. The measures taken in the field of industry, incentives given, the 1st Five-Year Industrial Development Plan in 1933 and the Çaykur Organization were examined.

Under the subtitle of legal and administrative reforms in the field of agriculture, agriculture, agricultural machinery, tax collected from agriculture, cooperatives, banking and legal regulations in this field were discussed..

Under the subtitle of reforms related to education in the field of agriculture, the Middle Agriculture School, which was opened in 12 places in 1922 with the law numbered 254, and the Agricultural Machinist School for three years in Ankara and Adana, where primary school graduates can attend, are discussed. Later, the education period of the Halkalı High Agricultural School, which was transferred from the Ottoman Empire to the Republic, was extended from three to four years since 1923, and the successful graduates were sent abroad and especially to Germany. Subjects such as the Ankara High School of Agriculture, which was opened in 1930, the High Institute of Agriculture established in Ankara in 1933, the Oldenburg Report and the Faculty of Agriculture were examined.

Under the subtitle of statism practices in the field of agriculture, farms established in the country under the leadership of Mustafa Kemal, seed breeding stations and their contributions to the agricultural field are discussed. Under the subtitle of agricultural machinery, tools and equipment, the number of machinery, tools and equipment used in the field of agriculture at the beginning of the Republic and their numbers in 1938 and 1950 were included. Accordingly, the state tried to set an example for mechanized agriculture in the country and to encourage the public for mechanized agriculture.

Under the title of Statism Practices in the Agricultural Field in Antalya during the Atatürk Period, the example of statism realized in Aksu in the field of agriculture in the Atatürk Period in Antalya was discussed. Later, subjects such as seed breeding station, citrus in Antalya, banana production in Alanya, irrigated agriculture, mechanized agriculture, arable land, increase in the product taken from the land, the benefit of the statism example to the villagers were examined.

The Ottoman Empire sent students abroad in the field of agriculture, brought experts from abroad, brought machinery, opened schools and aimed to increase agricultural activities in this way. In the field of agriculture in the Republic of Turkey, Atatürk period was followed exactly these purposes. However, a number of scientific and legal regulations were made in order for the people to cultivate more land and buy more products, and reorganized schools in the field of agriculture. 
Equipment Institution is established. By establishing agricultural breeding stations in the country, seeds with better yields are grown according to the region, soil, climate and vegetation. A major development initiative for the economic development of Turkey in the field of agriculture was launched at the Atatürk Period. Thus, the welfare and production of the villagers were increased with the reform movements in the agricultural field, and "agriculture-based industry" was developed with the production of industrial plants. During the Republican process, production has continuously increased as a result of the reforms made in the field of agriculture in the country except for natural reasons.

This research was conducted in the form of document analysis, the obtained data was analyzed and the text was formed by examining the obtained data.

\section{Giriş}

Osmanlı Devleti'nin son zamanlarında nüfusun büyük kısmı tarımla geçimini sağlamaktadır. I. Dünya Savaşı'na girilirken yapılan bir çalışmada ortalama zirai işleme büyüklüğünün en yüksek olduğu vilayet Bitlis’tir. Bitlis, Muş, Bingöl çevresinde ortalama işletme büyüklüğü 85 dönüme varmakta ve bu bölgedeki toprak dağılımını feodal üretim biçimi belirlemektedir (Mears, 1924: 20-24). Bu tarihte ülkede nüfusun \%82 tarım kesimindedir. Türkiye sınırları içinde kalan zirai arazisinin 5,4 milyon hektar ve bu arazinin yaklaşık \%80'ini kapsayan bölümde tahıl, \%7'sinde sebze, \%7'sinde bitkiler, \%4'ünde meyvecilik üretimi yapılır. Tahıl ve sebze üretimi en fazla Batı Anadolu, sınai bitkiler Akdeniz Bölgesi'nde Antalya ve Adana'da üretilir. Ege, Akdeniz ve Çukurova'da ulaşım kolaylığı nedeniyle piyasaya dönük üretim benimsenmiş ve bu nitelik ortalama işletme büyüklügüne yansımıştır. Mevcut işletmelerin küçük olması, işletme alanlarının parçalanmış olmasına karşın, arazi mülkiyetinde aşırı derecede bir yığılma görülür. 1913 yılında derebeyi ve toprak ağaları arazinin \% 65'ine sahiptir (Mears, 1924: 19-21).

Cumhuriyetin başlarında 1924 yılından sonra Medeni Kanunun 639. maddesine dayanarak Ağalar, Şeyhler, Beyler kendi bölgelerindeki toprakları mülkiyetlerine tapulu olarak geçirirler. Böylece bu bölgelerdeki ağalar ve şeyler devlet nezdinde legal konuma gelirler. Bu kişiler bundan sonra halk üzerinde daha fazla baskı yaparak devlet yerine bu kesim daha çok kazanmaya başlar (DİE, 1973: 24; Akbank, 1980: 12) Ülkede toprakların \%35'i köylünün, \%39'u derebeylerinin, \% 26's1 toprak ağalarının, ailelerin \%8'i topraksız, \%87'si ortakçı, \%4'ü ağa, \%1'i derebeyidir (Aydemir, 1999: 314).

1910'larda Anadolu köylüsünün yoksulluğunu ve genel niteliğini Kubilay Baysal eserinde "Köyler küçük topluluklar halinde, diş dünya ile olan ilişkileri kesilmiş bir biçimde yaşamaktadırlar. Köy ekonomisi kapalıdır. Para ve piyasa işlemleri toplam ekonomik faaliyetlerinin \%20'sini bile kapsamamaktadır. Köylü yalnız kendi ihtiyacı için ürettiğinden; üretimde herhangi bir yeniliği düşünmemektedir. Devletle köylü ilişkileri çoğu kere vergi ve askerlik işlemlerine inhisar etmektedir. Yol, su, okul, sağlik ocağ 1 vb. gibi kamu tesislerinin köye kadar uzanması hiç bir zaman söz konusu olmamıştır." şeklinde ifade etmektedir (Baysal, 1984;210). Kısaca, Anadolu köylüsü adeta kendi içinde, bağlı olduğu devlete ve de onun yöneticilerine yabancı düşmüş küçük birlikler halinde yaşar. Tarım makineli ve sulu tarıma dayanmayan ilkel şartlarda yapılır (Eldem,1970;275-280; DİE, 1973: 25).

Ülkede 1913 yılı Tarım Sayımı verilerine göre sürüm yapabilecek hayvan sayıs1 6,9 milyondan 1920'de 4,1 milyona düşmüştür. Buna göre daha az toprak ekilip dikilebilecektir. Yük hayvanlarında da bu kayıp devam edince 1920 yılında tarım ürünlerinde \%40, tütün, kuru üzüm, zeytinyağ 1 , ham ipek ve pamuk üretimine \%50 azalma olur (Pamuk, 1984:150-162). Ülkede 1924 yılında bu durumlardan dolay1 208 milyon ton tahıl ve un ithal edilir ve bu yılki toplam ithalat içindeki payı \%10'a ulaşır (Keyder, 1993: 97).

Osmanlı Devleti'nden Türkiye Cumhuriyeti'ne 1877-1878 Osmanl1-Rus Savaş1, 1909 Trablusgarp, 1912-1913 Balkan Savaşları, 1914-1918 I. Dünya Savaşı ve 1919-1922 Milli Mücadele derken ülke ve halk uzun süre savaşlara maruz kalır. Savaşlar sonunda ülkede erkek nüfusu azalarak daha çok yaşlı, kadın ve 
çocuklardan oluşan bir kitle vardır. Zaten Anadolu halkının çoğu tarımla ve hayvancılıkla geçimlerini sağlamaktadır.

Türkiye Cumhuriyeti'nin ilk genel nüfus sayımı ve tarım sayımı 1927 yılında yapılır. Ülke nüfusu 13 464564 ve km2'ye düşen nüfus yoğunluğu 17'dir. Yaklaşık on beş yıldır savaşan ülkede sadece tarım ve hayvancılığın yapılabildiği, zaten sanayinin de olmaması nedeniyle nüfusun büyük çoğunluğu çiftçilik yapmaktadır. Ekilebilir arazi tüm arazinin \%32'si, ekilen toprak ise \%4.86'dır. Ormanlar \%18, mera \%36, dağ ve taşlık arazi \%13, göller \%1 şeklindedir. Yine ekilen toprakların \%89.5'i hububat, \%3.9'u bakliyat, \%6.6’sını sınai ürünler oluşturur (Boratav, 1997;265-291; Aydemir,1999b; 349).

Ülkede nüfusun büyük kısmı toprağa bağlı, tarım ve hayvancılıkla geçinen kırsal alandadır (Çavdar, 1971: 17). Henüz daha kırsal alandaki feodalite düzeni devam eder (Aydemir, 1999:305). Feodaliteyi kırarak tarlası olmayan çiftçilere 1947 yılında çıkarılan Toprak Kanunu gereğince 1947-49 yılları arasında 626954 dönüm arazi 14099 aileye dağıtılır (Aydemir, 1999c:222).

Cumhuriyetin başlarında Türkiye tarıma dayalı bir ekonomiye sahip olan bir ülkede tarımsal üretimde çökmüş, tarımsal üretimi yapan dinamik nüfusun büyük kısmı savaşlarda ölmüştür. Ülkede ulaşım imkânı elverişsiz olduğundan pazar için üretim ortamından uzakta, içe dönük bir üretim tipi oluşmuş ve bu kapalı ekonomi şekli verimin artmasını sağlayan girişimleri de engellemektedir. Kıyı bölgelerinde ise dış pazarlarda rağbet gördüğü için daha çok üzüm, incir, tütün vb. ürünler yetiştirilir. Bu bölgelerdeki tarımsal faaliyetlerdeki geri kalmışlık sadece ulaşım, toprak zenginliğindeki farklılık veya teknolojik yetersizliklerden kaynaklanmamakta, büyük toprak sahiplerinin olması ve halkın çoğunun bu topraklarda irgat olarak çalışmaları verimin az olmasının nedenlerindendir (Kongar, 1983; 17; İnan, 1988; 292).

\section{Osmanlı Devleti'nde Tarım Alanında Reformlar}

Osmanlı Devleti'nin en önemli gelir kaynaklarından birini tarım alanından ve tarım ürünlerinden alınan vergiler oluştururken uzun süren savaşlar, kaybedilen topraklalar, ekilemeyen topraklar, ulaşım şartları gibi nedenlerle 19. Yüzyılda bu vergiler giderek azalmıştır. Osmanlı Devleti ile İngiltere arasında 1838 yılında yapılan serbest ticaret anlaşması sonrasında İngiltere Osmanlı topraklarını inceleyerek nerelerde hangi bitki türünün ekilebileceği ve nasıl daha fazla ürün alınabileceğini tespit edebilmek amaciyla uzmanlar göndermiştir. Uzmanların Türkiye ile ilgili raporları "Parliamentary Papers, Accounts and Papers (18391914), Commercial Reports from Consular offkes in Turkey, annual reports, Great Britain" başlı̆g 1 altında yer alır. Bu raporlarda Konya, Ankara, Edirne, Kastamonu, Sivas, Samsun, Giresun, Antalya, Ayvalık, Adana, Mersin ve İskenderun'a ait bilgiler yer alır (Önsoy, 1988: 37-45; Güran, 1992: 219-2).

II. Abdülhamid zamanında Almanya ve Avusturya- Macaristan İmparatorluğu ile siyasi, ekonomik, askeri, eğitim ve kültürel alanlarda ilişkiler İngiltere ve Fransa'ya göre giderek artmıştır. Bu ilişkiler İttihat ve Terakki Hükümetleri süresince de devam etmiştir. Özellikle 1860 sonrasında ülkede sivil gazetelerin çıkması, yazar ve fikir adamlarının yazılarının, görüşlerinin, Hükümete tavsiyeleri veya eleştirileri yer almaya başlar. Osmanlı Devleti yöneticileri ülkenin tarıma dayalı ekonomisinin son zamanlarda geri kaldığını tespit ederek ülkede tarım sayımları yaptırmıştır. İttihat ve Terakki döneminde yönetimin yanında mecmualarda da ülkenin tarım alanında yenileşmeye gitmesi gerektiği hususunda yazılar çıkar. Genel olarak ülkede geri kalan tarım alanında yenileşme çalışmaları yapılmak istenmiş ancak savaşlar nedeniyle istenilen ölçüde yenilik yapılamaz (Owen, 1981:2544, İnalcık, 1990: 1-11).

Osmanlı Devleti'nin son döneminde Cavid Bey'in ülkede tarım alanına gelişmelerin sağlanması hususunda faaliyetleri yanında Ulum-1 İktisadiye ve İçtimaiye Mecmuası'nda sık sık yazılar çıkarmaktadır. Yazarlardan Ahmet Muhtar Orman ve Maadin Nazırı Aristidi Paşa'ya ithafen yazdığı mektupta Osmanlı ülkesinin bir tarım ülkesi, halkın tarıma yatkın olmasına karşın ülkede tarımın çağın gerisinde kaldığı, bu nedenle ülkede tarım bölgelerinin belirlenmesi için Avrupa'dan alanında uzman ziraat mühendisleri getirtilmeli, ülkedeki ziraatçıların da katılımıyla heyetler oluşturularak ülkenin arazi ve iklim şartları, bitki örtüsü incelenerek hangi tür bitkilerden en iyi şekilde nasıl ürün alınabileceği konunda incelemelerde bulunulması, yapılan araştırmalar sonunda raporlar hazırlanması, örnek çiftliklerin ve ziraat okullarının 
nerelerde kurulması gerektiği konuları yer almıştır. Hatta bunun için bir maliyet hesaplaması da eklemiştir. Mektupta ilaveten ülkede Tarım Genel Müdürlügü’nün kurulması, ormanları inceleyecek uzmanların, su kanallarını düzenleyecek mühendisler, süt için kimyager, inek, koyun, keçi ve diğer hayvan türleri için uzmanlar yurt dışından getirtilmelidir (Muhtar, 2015: 32-45).

\section{Atatürk Dönemi’nde Tarım Alanında Reformlar}

Osmanlı Devleti'ne tarım alanında torağı olmayan çiftçilere toprak dağııımı, ekilmeyen toprakların ekilmesi, ülkeye yabancı uzmanların davet edilerek toprak yapısı, bitki örtüsü ve iklim şartlarına göre ülkede hangi bitkilerin ve hayvanların yetiştirilmesi gerektiği, yurt dışına öğrenci ve uzman göndererek oralarda incelemelerde bulunulması, tarım alanında eğitim ve araştırma kurumlarının açılması, tohum ve hayvan sslah istasyonları, üretme çiftlikleri açılarak tohum, ürün, makine kullanımı, damızlık hayvan üretimi gibi konularda halka örnek olmak ve ülkenin tarım ürünleri artırılmak istenmiştir.

Cumhuriyetin başlarında erkek nüfus azlığı, ekilen toprak ve ürünlerin azlığı yeni kurulan ülkenin devleti kurması, nesli eğitmesi, sanayiyi oluşturması, Osmanlı'dan kalan borçları ödemesi, kısacası kalkınması gerekiyordu. Ülke dış borç almak istemediğine göre geriye sadece halkın emeğine, ürününe ihtiyaç vardı. Bu nedenle öncelikle Osmanlı Devleti'nde yapılanlar incelenmiş, daha sonra tarım alanında yasalar çıkartılır, bilimsel toplantılar düzenlenir, yurt dışından uzmanlar getirtilir, yurt dışına uzmanlar gönderilir, modern eğitim kurumları açılır, ülkeye makineli tarım için alet, edevat ve makine getirtilir, tohum ve hayvan ıslah istasyonları, örnek uygulama çiftlikleri kurulur. Böylece daha fazla arazi ekilerek, ürün artış1 sağlanması, ülkede sanayi bitkileri ekilerek bunlara yönelik fabrikalar kurulur. Böylece halkın beslenmesi, giyinmesi, fazla ürünle kalkınması sağlanırken devlet tarımdan aldığı vergilerle devleti yapılandırırken sermaye birikimini sağlamak, fabrikalar kurmak, borcunu ödemek, ülkenin alt yapı ve üst yapı yatırımlarını gerçekleştirmek istenmiştir.

\subsection{Tarım Alanında Bilimsel ve İdari Etkinlikler}

Tarım alanında Büyük Taarruz sonrası Lozan Barış Konferansı'nda görüşmeler kesintiye uğradığı bir sırada 17 Şubat - 4 Mart 1923 tarihleri arasında İzmir'de “I. Türkiye İktisat Kongresi” düzenlenerek ülkenin acil gereken ekonomik yapısına yön verilmeye çalışılmıştır (Sağlam, 1977: 77; İnan, 1982: 12; Minibaş, 1989: 82-83). I. Türkiye İktisat Kongresi kararları arasında ormancılık, hayvancılığın geliştirilmesi, tütün ve tarım ticaretinin serbest bırakılması, Ziraat Bankası'nın yeniden düzenlenmesi, ipekçilikle pancar ve kendir üretiminin geliştirilmesi, tarımda makineleşmeye gidilmesi, gümrük politikalarının tarımı geliştirecek şekilde olması, aşar vergisinin kaldırılması gibi önemli kararlar daha çok tarımı düzenlemek için alınan kararlardır. Zira hiç bir önemli sanayi kuruluşu olmayan ülkenin önce tarımsal gelişme sayesinde kırsal kesimin refah seviyesini yükselterek sermayeye, sonra da bununla sanayileşmeye gitmesi gerekmektedir (Keyder, 1975: 102; Görgün, 1977: 77; İnan, 1982: 24-31; Dura, 1991: 11,39; Dinler,1993:191).

Dünya'da yaşanan 1929 ekonomik buhranı nedeniyle ülkede Milli İktisat ve Tasarruf Cemiyeti kurulur. Bu cemiyet tarafindan 1931 yılında Ankara'da I. Ziraat Kongresi düzenlenir. Kongreye çok sayıda uzman katılmış ve ülkede ziraat alanında nelerin yapılabileceği tartışılmıştır. Bu cemiyet daha sora I. Sanayi Kongresi'nin toplanmasında da etkin olmuştur.

Cumhuriyetin başlarında Ziraat Bakanı Mehmet Sabri Bey Rusya ziyareti sırasındaki incelemeleri sonucu buradaki tarım faaliyetlerinden etkilenmiş ve ülkede de tarım alanında yeni ürünlerin ekilmesi ve mevcut ürünlerin çoğaltılması gereğini düşünmüştür. Daha sonra iki ülke arasında varılan mutabakat sonrasında Rus Ziraat Bilimci Prof. Dr. Jukovsk 1925-1928 yılları arasında Türkiye'ye gelerek incelemelerde bulunmuştur. Jukovsk ziraat alanları ile hangi bitkilerin nerelerde daha verimli yetişebileceği konusunda bilimsel bir rapor hazırlamıştır. M. Jukovski'nin başkanlığında bir ilim heyetince derlenen 10000 numune Rusya'ya götürülmüş, 26 Profesör ve uzmanlarca 50 kadar çiftlikte tetkik ve tecrübelere tabi tutulmuş ve Leningrad Ziraat Enstitüsü'nde bir laboratuvarda "Türk Ziraat Pavyonu" açılmıştır. Türk zirai bitkilerinin bilimsel tasnifi yapılarak 1933 yılında 1000 sayfaya yaklaşan bir kitapta yayınlanır. Akademi üyesi H. İ. Vavilov'un başkanlığında yürütülen bu çalışma Türk Ziraatında uygulamaya geçirilemez. Bu ülkenin ne 
denli geri olduğu, ziraatı dahi bilimsel olmadan eski geleneklere göre devam ettirdiğini gösterir. Böylece çiftçiler daha çok motive edilerek toprağa işler hale gelmesi öngörülür (Aruoba, 1982: 79-81).

1930'lu yıllarda ülkede meyve üretimi açısından Ziraat Bakanlığı uzmanlara incelemeler yaptırır. Heyet Manisa'da üzüm yetiştiriciliği, Manisa'da Kaliforniya tarzı ile üzüm kurutulması, Selimşahlar Köyü çevresinde de kavun yetiştirilmesi hususunda köylüler bilgilendirilir (Lewis, 1988: 461).

Türkiye'de Ziraat Bakanlığı'nca oluşturulan heyetler ülkenin çeşitli yerlerinde tarımın işleyişi ve problemleri ile ilgili incelemelerde bulunur. Bu heyetlerde daha çok Alman bilim adamları ve uzmanları yer alır. 1936 yılında Ege' de ve özellikle Tire ve çevresinde incelemelerde bulunan heyet Tire'yi Ege Bölgesi'nin en yüksek oranda kendir üreten yeri olarak tespit eder, zira Tire 1936 yılında bölgenin kendir üretiminin $\% 65$ 'ni sağlamaktadır.

Ülkede sanayinin kalkınması yine tarım ürünlerinin artması, sanayi bitkilerinin çoğalması, fabrikalarda işlenmesi ile hem köylünün hem de ülkenin kalkınması amaçlanır. Ülkede sanayi alanında alınan tedbirler, verilen teşvikler, dünya ekonomik buhranı ve ülkenin içinde bulunduğu şartlar nedeniyle amacına ulaşamayınca Hükümet devletçilik politikasına geçme kararı alır. Bu karar gereğince 1933 yılında I. Beş Yıllık Sanayi Kalkınma Planı hazırlanır.

I. Beş Yıllık Sanayi Kalkınma Planı'nda tekstil sanayii, kendir-keten sanayii, suni ipek, selüloz ve kâğıt tesisleri, şeker sanayii, süngercilik ve gül sanayileri yer alır. Planın uygulanmasına 1934 yılında başlanır, planda öngörülen tesisler beş yıl içinde tamamlanarak işletmeye açılır. Özellikle toprağın verimini artıracak olan tekniğin tarıma uygulanmasının, bütün bir endüstri hayatının gelişmesi ile mümkün olabileceğini de ortaya koyar (Tanilli, 1994: 285).

Devlet Ziraat İşletmeleri'ne bağlı olan Çaykur Teşkilatı, Tekel Genel Müdürlügü’ne devredilmiş, Devlet Ziraat İşletmeleri kurumu da "Devlet Üretme Çiftlikleri Genel Müdürlüğü" şeklinde teşkilatlanmıştır. Rize'de Çaykur'da makine mühendisi İngiliz Mr. Gibbart ile çaycı Mr. Allen görev yaparken kalifiye eleman yetiştirilmesi yönünde çalışmalara başlar, 30 civarındaki çay imalat işletmelerin de kurslar açılır ve teknik kalifiye eleman yetiştirilmesine çaba harcanır. Burada İngiliz çay uzmanı Mr. Harler bölgeyi dolaşarak çay üreticileri ile temas kurar, çayın yetiştirilmesi ve mahsulün alınması konusunda tavsiyelerde bulunur (Gençay,1989; S. 12; Türk Parlamento Tarihi IV. Dönem 1931-1935; 365). Bu gelişmelerden sonra 27.3.1940 tarih ve 3788 sayılı kanunla çay üretimi teknik, mali ve idari esaslara bağlanır (Aydemir,1999b; 320-324).

Ülkede ilk yıllarda 100 bin hektar alanda 40 bin tona yakın pamuk üretilir. 1923 y1lında 3,7 milyon dolarlık ihracat, 1930'da 7,8, 1950'de 69 milyon dolara ulaşır. Bu pamuk üretimi nedeniyle çırçır, basma, dokuma ve bez üretim tesisleri sanayileşmede örnek oluşturur. Bu üretimleri desteklemek amaciyla 3 Haziran 1933 tarihinde Sümerbank kurulur. Ülkede 9 Ekim 1937'de Nazilli Basma Fabrikası ilk dokuma örneğini oluştururken ardından zaman içinde bu alanda 20 tesis daha ülkeye kazandırılır (Önder, 1988: 119).

\subsection{Tarım Alanında Yasal ve İdari Reformlar}

Milli Mücadele Dönemi içinde Mustafa Kemal 1922 yılı Mart ayında Mecliste yaptı̆̆ı konuşmada konuya tarım konusuna düşüncelerini ifade etmiştir: "Yedi asırdan beri, cihanın çeşitli uzak köşelerine sevk ederek, kanlarını akıttığımız, kemiklerini o topraklarda bıraktığımız ve yedi asırdan beri emeklerini ellerinden alıp israf eylediğimiz ve buna karşılık daima tahkir ve tezlil ettiğimiz ve bunca fedakârlık ve ihsanlarına karşı, nankörlük, küstahlık, cabbarlıkla uşak menzilesine indirmek istediğimiz, asil Sahib'in huzurunda, hem tam bir utanç, hem tam bir saygı ile hakiki vaziyetimi alalım..." (Aydemir,1999:258-359). Buna göre Mustafa Kemal köylülerin gelir düzeylerini ve yaşam şartlarını düzenlemek için savaştan sonra hemen yeni düzenlemelerin yapılacağ 1 haberini vermektedir.

25 Mart 1924'de yürürlüğe giren 432 sayılı “Ziraat ve Ticaret Vekâletleri Teşkili Hakkında Kanun”un 1. maddesi ile daha önce tarımla ilgili hizmetleri yürütmekle görevli İktisat Vekâleti kaldırılarak yerine Ziraat ve Ticaret Vekâletleri kurulmuştur (Düstur, 3.Tertip, C.5, 1924: 670) 
I. Türkiye İktisat Kongresi kararları hemen uygulamaya konulur (Türkiye İktisat Kongresi, 1923, 1981: 394). Ülkede 1924 yılında Köy Kanunu çıkartılarak köyde yaşayanlara kente göre ayrıcalıklar ile üretimde kolaylıklar sağlanmıştır. 21 Nisan 1924 tarih ve 498 sayılı İtibar-1 Zirai Birliği Kanunu ile kooperatifçilik ile ilgili yeni uygulamalar başlatılarak (Düstur, 3.Tertip, C.5, 1924: 1090), Zirai Birlikler Kanunu çıkarılır. Kısa süreli küçük tarım kredileri Ziraat Bankası dışında verilmeye başlanır. 17 Şubat 1925'te 552 sayılı kanunla Aşar Vergisi ve 26 Şubat 1925 tarihinde 556 sayılı kanunla Tütün İnhisarı kaldırılır. 19.05.1925 tarihinde Sanayi ve Maadin Bankası kurularak tüm fabrikalar (Hereke, Bakırköy, Feshane Dokuma fabrikaları ile Beykoz Deri ve Kundura fabrikası, Tosya ve Maraş çeltik fabrikaları) bu teşkilata devredilir. Aynı yıl Bursa Mensucat Fabrikası açılır. 1926 yılında Ziraat Bankası sermaye artırarak daha fazla köylülere kredi sağlanır (Mülayim, 1998;15-17).

Ülkede yıllık 5,5 milyon metre yünlü ihtiyacından 3766000 metresi, şekerin tümü, 4 milyon kg der ithal edilmektedir. Bu nedenle sanayi bitkilerinin yaygınlaşma sürecinde ilk Şeker Fabrikası Alpullu 1926' de faaliyet geçer, bunu özel ve mahalli teşebbüs olan Uşak Fabrikası izler. 1927 yılında Bünyan Dokuma Fabrikası açılır. 5 Haziran 1929 tarihinde 1470 sayılı Zirai Kredi Kooperatifleri Kanunu çıkartılarak çiftçilere uygun kredi sağlanır (Cevdet Nasuhi, 1931: 1934). Daha sonra Eskişehir fabrikasının temeli atılır, 1934'te Turhal Şeker fabrikası da dâhil olur. Bu kuruluşlar 1935 yılında Kamu İktisadi Teşekkülü (KİT) adıyla faaliyetlerine devam eder (Aydemir, 1999b: 362).

1925 'de kabul edilen bir kanunla birlikte; Devlete ait arazilerin köylüyü topraklandırmak amacı ile köylüye dağıtılmasına başlanmıştır (Tezel, 1994: 371-372). Atatürk toprağı olmayan çiftçilerin topraklandırılmasına büyük önem verir ve bir an önce konuyla ilgili bir yasanın çıkmasını isterdi. Mustafa Kemal "Toprak Kanununun bir neticeye varmasını, Meclisin yüksek himmetinden beklerim. Her Türk çiftçi ailesinin, geçineceği ve çalışacağı toprağa malik olması, behemehal lazımdır. Vatanın sağlam temel ve imarı bu esastadır." (Aydemir, 1999b; 330; Turan, 2000; 103-114). İlk on yılda köylüye 1077526 dönüm arazi dağıtılır. 1927-1929 yılları arasında çıkarılan yasalarla toprak reformuna gidilmiş ve topraksız ailelere toprak dağıtımı gerçekleştirilmiştir (Aksoy, 1971: 59). Ülkede 1947-50 yılları arasında Çiftçiyi Topraklandırma Kanunu gereğince $1497148 \mathrm{~m} 2$ arazi 32688 aileye dağıtılmıştır. Toprak sahibi olan köylünün toprak, tohumluk, tarım araçları borçlarının 20 yılda ödenmesi sağlanmıştır. İlk işletilen arazi, yeni yetiştirilmeye başlanan fidanlıklar, bağlar ve zeytinliklerden belirli bir süre için vergi alınmaması kuralı kabul edilmiştir (Aydemir, 1999b; 325).

24 Mayıs 1930 tarihli 1641 numaralı kanun ile ülke dışından getirilecek ıslah edilmiş tohumların gümrük vergisinden muaf tutulması sağlanmıştır. 1936 yılında çıkarılan bir yasa ile ülkede çeltik ekimi belirli kurallara bağlanır. Buna göre her ilde çeltik komisyonları kurulacak ve ekim bu komisyonlarca yürütülecektir. $\mathrm{Bu}$ arada, devletin tarım ve hayvancılık konusunda iktisadi ve ticari faaliyetlere doğrudan katılma zorunluluğu ortaya çıkar ve bunun sonucu olarak; TMO, EBK, Türkiye Şeker Fabrikaları A.Ş., Yem Sanayii, Yapağı ve Tiftik A.Ş., TZDK, SEK gibi yeni KİT'leri meydana getirilir. Aynı süre içinde bitkisel üretime götürülmekte olan kamu hizmetlerinin çeşit ve sayısı da giderek artar. T.C. Ziraat Bankası ve TKK'leri tarafından yerine getirilen kredi kullanımı, sektörü ciddi şekilde etkileyen bir fonksiyon görür. Kullanılan kredi hacmi 1923'de 8 milyon TL, 1938'de 48 milyon TL, 1950'de 400 milyon TL'ye ulaşır (Kireyev,1987: 673-649).

Tarım aletleri, makineleri ve ilaçlarının satın alınarak halka tanıtılması amacıyla 1937 yılında 3130 Saylı Kanun ile Zirai Kombinalar İdaresi kurulur. Kombinalar aracılığg ile kırsal alanda ve tarımla uğraşanlara tarım aletleri, tarım makineleri, tarımsal ilaçlar sağlanmaya çalışılır.

1938 yılında 3308 Sayılı Kanun ile Devlet Ziraat İşletmeleri Kurumu kurulur. Bu kurum bölgesel olarak tarım usulleri ve tarım türlerini yaymada ve zamanlarını belirleyip uygulamada halka örnek olma, rehberlik yapmak istenmiştir. Bu hedefle tarımsal işletme merkezleri, fabrika ve atölye kurmak, bunları işletmenin yanında silo, ambar işleri yapmak, tarım işletmeleri oluşturmak ya da bunlara maddi iştirakte bulunmak genel olarak kurumun görevleri olarak belirlenmiştir (Çalgüner, 1971: 41-42). 
Hükümet yurtdışından tarım makinelerinin ithalatından alınan vergileri kaldırarak Ziraat Bankası aracılığ 1 ile tarım üretim makinelerinin ithalatını desteklenmesi ile yaklaşık 2000 traktör ülkeye getirtilir. Böylece ülkede tarım alanında alınan tedbirlerle 1928 yılında tarım verileri 1913 yılı verilerine tekrar ulaşır (Keyder,1993: 35-36).

Atatürk Dönemi'nde halkın ürünlerini değerlendirmesi ve daha uygun ürünlere sahip olabilmesi için tarım kooperatifçiliğine önem verilerek 1929 yılında Tarım Kredi Kooperatifleri Yasası ve 21 Ekim 1935 tarihinde 2836 sayılı yasa ile buğday üreticisini desteklemek ve korumak amacıyla Tarım Satı̧ Kooperatifleri Yasası çıkartılır (Tecer, 2006: 76). Tarım kredi kooperatiflerinin sayıs1 1929'da 65'ten 1938'de 589'a; kooperatiflere üye olanların sayısı da 1929'da 4 000'den 1938'de 114 000'e yükselmiştir. Atatürk kooperatifçiliğini desteklemek amacıyla Mersin Silifke'de 36 çiftçi ile Tekir Tarım Kredi Kooperatifi kurucusu ve bir numaralı ortağı olur (Atatürk'ün Tamim, Telgraf ve Beyannameleri IV, 1964: 576).

1934 yılında ülkede Bursa'da ilk süt tozu fabrikası, Isparta'da Gülyağı fabrikası açılır. 1935 yılında Türkiye şeker Fabrikaları Anonim Şirketi, Kayseri Bez fabrikası kurulur. 1937 yılında ormanları korumak amacıyla Orman Kanunu, Konya Ereğli Bez fabrikası açılır. 1938 yılında Gemlik Suni İpek, Bursa Merinos fabrikaları açılır, köylünün üretimlerini almak için Toprak Mahsulleri Ofisi kurulur (Çalgüner, 1971: 41-42).

12 Ocak 1925 tarihinde 541 sayılı Pamuklara Arız Olan Haşarat ve Emrazın İmha ve Tedavisi ve Tohumların Islahı Hakkında Kanun çıkartılır. Daha sonra 28 Mayıs 1927 tarihinde 1056 sayılı Kanun, 29 Ocak 1936 tarih ve 2906 sayılı Nebatları Hastalık ve Zararlı Böceklerden Koruma Kanunu Ziraat Bakanlığı'’na önemli yükümlülükler verir. Bu yükümlülük nedeniyle Ankara'da Merkez Mücadele Enstitüsü, İzmir Bornova'da ve Adana'da birer mücadele istasyonu kurulur (Tekeli-İlkin,1988: 52; Toprak, 1988: 28).

Bağcılık alanında Cumhuriyet dönemine Osmanlı'dan 80 dekar büyüklügündeki Erenköy Amerikan Asma Fidanlığı intikal etmiştir. Ele alınan dönemde Ankara, Bilecik, Halkalı, Kırklareli, Tekirdağ ve Manisa'da toplam alanı 1307 dekarı bulan yeni fidanlıklar kurulmuştur. Üreticiye 1924'te 6725 fidan dağıtılmışken bu sayı 1938'de 3 022 965'e ulaşmıştır (Toprak, 1988: 27-28).

2 Aralık 1925 tarih ve 682 sayılı Her Nevi Fidan ve Tohumların Meccanen Tevzi ve Devlet Uhdesinde Bulunan Arazinin Fidanlık İhdası İçin Ziraat Vekâleti'ne ve İdarei Hususiyelere Bila Bedel Tefvizi Hakkında Kanun, 24 Mayıs 1930 tarih ve 1641 sayılı Tohumlukların Gümrük Resimlerinden İstisnası Hakkında Kanun, 2 Haziran 1930 tarih ve 1682 sayılı Ziraat Bankasınca Tedarik Olunacak Tohumların Satış Zararlarının Ödenmesi Hakkında Kanun, 1934 yılında kabul edilen 2654 sayılı Tohum Üretme Çiftlikleri Kanunu çıkartılır. Bu kanunlar devlet üretme çiftlikleri ile ıslah istasyonlarının misyonunu belirler (Tekeli-İlkin, 1988: 46).

\subsection{Tarım Alanında Eğitimle İlgili Reformlar}

TBMM Hükümeti döneminde 1922 yılında 254 sayılı yasa ile 12 yerde Orta Ziraat Okulu aç1lır (Düstur, III. Tertip, C: 3, 1922: 177; Ayas 1948: 641). Bu okul türü kısa sürede Ankara, Bursa, Adana, Konya, Kastamonu, Erzurum, Çorum, Erzincan, Edirne, İzmir, Sivas ve Kepsut'a da açılır. Tarım alanında makineleşmenin yaygınlaştırılabilmesi amacıyla Ankara ve Adana' da ilkokul mezunlarının gidebildiği üç yıl süreli Ziraat Makinist Okulu açılır (Tekeli- İlkin, 1988:43).

Osmanlı Devleti'nden Cumhuriyete intikal eden Halkalı Yüksek Ziraat Okulu öğrenim süresi 1923 yılından itibaren üç yıldan dört yıla çıkarılarak mezunları arasından başarılı olan yurtdışına ve özellikle de Almanya'ya gönderilmeye başlanır. Bu öğrencilerden 26's1 ülkeye döndügünde 1933 yılında Ankara'da Yüksek Ziraat Enstitüsü'nde görev alır. 1928 yılında Halkalı Ziraat Okulu ile diğer orta dereceli ziraat okulları geçici olarak kapatılır (Tezel, 1994: 414).

Cumhuriyetin ilk yıllarında Ankara'da Meteoroloji Genel Müdürlüğü’nün yerinde 1930 tarihinde Ankara Ziraat Yüksek Mektebi açılır. Osmanlı'dan intikal eden Halkalı ve diğer ziraat uygulama okullarının kapatılması sonrasında 1930 yılında İstanbul, Bursa, İzmir ve Adana' da birer orta ziraat okulu açılır. Bu okullara artık ortaokulu bitirenler alınması nedeniyle bu okulların lise düzeyinde olduğu görülür. Ankara'da 
1930 yılında kurulan Yüksek Ziraat Okulu ziraat, orman, baytar, ziraat sanatları, ulumu tabiye alanlarında beş bölümden oluşan 16 Haziran 1933 tarihinde 2291 sayılı kanunla Yüksek Ziraat Enstitüsü’ne dönüştürülür (Resmi Gazete, 20 Haziran 1933 Sayı: 2432; Ayas, 1948: 662; Tekeli-İlkin, 1988: 43).

Almanya'da eğitim görenlerden biri olan Reşat Muhlis Erkmen, Leipzig Üniversitesi’nden Prof. Dr. Falke ve Prusyalı Prof. Dr. Oldenburg başkanlıklarında iki uzman heyeti Türkiye'ye davet eder. 1927 yılında Atatürk'ün talimatı ile Türkiye'de ziraatın yapısını incelemek, ziraatı geliştirmek, ürünleri artırmak ve bu alanda bir yükseköğretimin nasıl yapılacağı hususlarında bir rapor hazırlamak için davet edilen ve 1928 yılında ülkeye gelen heyetin başında Oldenburg vardır. Bu heyet daha sonra Oldenberg Heyeti raporu da Oldenburg Raporu olarak anılır. Bu heyetlerin incelemeleri ve tavsiyeleri ile Ankara Ziraat Enstitüsü kurulur (Mağden 1959: 58).

Bu Enstitü Ankara Üniversitesi'nin kurulması sonrasında Ziraat Fakültesi olur. Enstitü 1935 yılında Ankara'da Ziraat Müdürleri Kursu açar ve 23 vilayetin müdürü kursa davet edilir. Ziraat okulları ile diğer tarım kuruluşları teknik bilgileri çiftçilere ulaştırmak ve teknik elemanlara yeni bilgiler vermek amacı ile kurslar açarak bu alandaki eksiklikleri gidermek için önemli aşamalar kaydetmiştir.

\subsection{Tarım Alanında Devletçilik Uygulamaları}

Tarla bitkilerinde ıslah çalışmaları üç aşamada gerçekleşir. İlk aşamada 1slah ve deneme istasyonlarında tohumlar 1slah edilecek veya yeni bitki türleri bulanacak, ikinci aşamada bu bitki türlerinin en iyi şekildeki üretim teknikleri araştırılacak ve köylülere tanıtılacak, üçüncü aşamada üretme çiftliklerinde isla edilen tohum yeteri kadar çoğaltılarak köylülere dağıtılacaktır (Gökköl, 1935: 145). Bu çalışmalar hububat konusunda Ziraat Bakanlı̆̆ı'na bağlı kurumlar, pamuk Ziraat Bakanlığı'na bağlı özel bir müdürlük, şeker pancarı Şeker Fabrikaları, tütün ise Tekel eliyle yürütülmeye çalışı1ır.

\subsection{1. Çiftlik Uygulamaları}

Mustafa Kemal ülkede yetişmiş eleman yokluğu nedeniyle Ankara'da Gazi Çiftliğini kurma kararı vermiştir. Bunun için 1924 yılının Mayıs ayında Ankara-Keçiören'deki Ziraat Mektebi öğretmenlerinden Ali Numan Bey'e fikrini açarak "Bu çiftlik, memlekette çağdaş ziraat usulünü yerleştirmek için örnek teşkil edecektir." demiştir (Tayşi, 1940: 3, Gökköl, 1935: 195). Ali Numan Kıraç "Drayfarming Araştırmaları" isimli kitabında konuyu şöyle özetlemiştir: "Drayfarming, yağışı az olan veya yağmurları uygun zamanlarda düşmeyen bir bölgede, sulamaksızın başarılı ürün yetiştirmek usulüdür (Ulus 8 Temmuz1949). Memleketimizde Orta Anadolu Yaylası az yağışlıdır. Trakya ve deniz kıyıları mıntıkalarımızda da bazen yağışların zirai mevsimlere dağılışında uygunsuzluklar vardır. Daha doğrusu kuraklık ve etkileri memleketimizin her yerinde zaman zaman ziraatımızı tehdit eder. Bu durumda, kuraklığın gereklerine göre ve memleketimizin ihtiyaçlarına uyan yerli bir ziraat sistemi ile çalışmak gerekiyor." (Gökköl, 1935: 194; Avcıŏlu, 1969: 179).

Numan Kıraç Atatürk tarafından akıncı bir rol için seçilmiş, Amerika'ya gönderilmiş, orada bizde ziraatın ilerletilmesi için neler öğrenmek lâzım gelirse onları bulmuş, seçmiş, öğrenmiş, Eskişehir Kuru Ziraat İstasyonu'nu 1929 yılında kurmuştur. Bu istasyonda Ali Numan Kıraç tarafından çok önemli çalışmalar yürütülmüş ve birçok ülkede "Türk Mucizesi” olarak özellikle buğday üretimindeki 1slah çalışmaları örnek alınmıştır.

Mustafa Kemal Türkiye'de daha verimli tarım yapılabilmesi amacıyla 1925 yılından sonra satın aldığ topraklarla çiftlik kurmaya başlamıştır. Atatürk Ankara'daki Gazi Çiftliği’ne 1925 yılında Macaristan'dan damızlık Simental ırkı sığır getirterek halka örnek olmaya çalışır. Zamanla bu çiftliklerin sayısı yediye ulaşmıştır. Mustafa Kemal bu çiftlikleri tek bir yönetim altında birleştirip "Orman Çiftliği" olarak adlandırmıştır. Atatürk'ün Ankara'daki çiftliklerini konu alan kitaplarda, tarım, hayvancılık ve sınaî üretimdeki başarılar çok önemsenmekle birlikte eğitim, eğlendinlen ve çağdaş bir başkent yaratma amacına özellikle dikkat çekilmektedir (Avcıoğlu, 1969: 179). 
Orman Çiftliği arazilerinde, yalnızca tarımsal üretimle yetinilmemiş, 1926 yılından başlamak üzere tarım ve hayvansal ürünlerin işlenebilmesi amacıyla; firın, deri ve demir atölyeleri, pastörize süt, üzüm suyu, bira ve şarap fabrikaları kurulmuştur. Atatürk Çiftliklerinin aynı zamanda bir eğitim ve eğlendinlen alanı olarak da değerlendirildiği anlaşılmaktadır. Yüksek Ziraat Enstitüsüne girecek öğrencilere, Çiftlikte staj yapma zorunluluğu getirilerek, tarım teknikleri ve tarım makinelerini kullanma konusunda yetişmeleri sağlanmıştır. Ayrıca, Çiftlikte çalışanların çocukları için bir okul yapılmıştır (Aysan, 1987;86).

Atatürk 11.06.1937 günlü bağış mektubunda bu çiftliklerin kuruluş amacını; "... Bu müesseseler; ilk senelerden başlayan bütün kazançlarını inkişaflarına sarf ederek büyük küçük müteaddit fabrika ve imalathaneler tesis etmişler, bütün ziraat makine ve aletlerini yerinde ve faydalı şekilde kullanarak bunların hepsini tamir ve mühim bir kısmını yeniden imal edecek tesisat vücuda getirmişler, yerli ve yabancı birçok hayvan ırkları üzerinde çift ve mahsul bakımından yaptıkları tetkikler neticesinde bunların muhite en elverişli ve verimli olanlarını tespit etmişler, kooperatif teşkili suretiyle veya ayni mahiyette başka suretlerle civar köylerle beraber faydalı şekilde çalışışlardır... Çiftliklerin, yerine göre, araziyi ıslah ve tanzim etmek, muhitlerini güzelleștirmek, halka gezecek, eğlenecek ve dinlenecek sıhi yerler, hilesiz ve nefis gıda maddeleri temin eylemek, bazı yerlerde ihtikârla fiylî ve muvaffakiyetli mücadelede bulunmak gibi hizmetleri de zikre şayandır... Tecrübelerini müspet iş sahasından alan bu müesseselerin; ziraat usullerini düzeltme, istihsalatı artırma ve köyleri kalkındırma yolunda devletçe alınan ve alınacak olan tedbirlerin hüsnü intihap ve inkişafına çok müsait birer âmil ve mesnet olacaklarına kani bulunuyorum." sözleriyle açıklamıştır (Boratav, 1974;133-159).

Atatürk, Ankara'da Orman, Yağmurbaba, Balgat, Macun, Güvercinlik, Tahar, Etimesut, Çakırlar çiftliklerinden oluşan "Orman Çiftliği" ile, yurdun değişik bölgelerinde kurduğu 6 adet çiftliğini amaçları doğrultusunda yönetilmesi için, 11.06.1937 günlü bir yazıyla Hazineye bağışlamıştır. Atatürk Çiftliklerinin yönetilmesi için 01.01.1938 günlü, 3308 sayılı Yasa ile Devlet Ziraat İşletmeleri Kurumu (DZIKK) kurulmuş ve bütün taşınmazlar bu Kuruma devredilmiştir. Çiftlikler, bu statülerini 11 yıl sürdürebilmişlerdir. 07.06.1949 günlü, 5433 sayılı Yasayla, DZİK, Zirai Kombinalar İdaresi ile birleştirilerek Devlet Üretme Çiftliği olarak yeniden yapılandırılmış, Orman Çiftliği dışındaki çiftlikler kapatılmıştır. Orman Çiftliği ise, 24.03.1950 günlü, 5659 sayılı Yasa ile; "Atatürk Orman Çiftliği" olarak adlandırılıp, Tarım Bakanlığına bağlı bir tüzel kişilik statüsüne kavuşturulmuştur (Arat, 1969;166).

Devlet Ziraat işletmeleri kurumu zirai makine, araç parkı ve zirai mücadele ilaçlarıyla köylünün ekim, nadas, harmanına yardım etme, tarlalarında tarımsal mücadele yaparak çiftçileri modern tarıma alıştırma amacıyla kurulmuştur. Bu kurum çalışmalarını çokça tahıl türleri ve hayvan ırklarının iyileştirilmesi yönünde olmuştur (Tezel, 1994: 415).

\subsubsection{Tohum Islah istasyonları Uygulamaları}

Tohumluğun kalite kontrolü üzerinde ilk bilimsel çalışmalar 1869 yılında Almanya'nın Tharand kasabasında kurulan laboratuvarda Friedrick Nobbe tarafından başlatılmıştır. Türkiye'de çeşit geliştirme, tohumluk alanındaki ilk bilimsel çalışmalar 1925 yılında başlar. Türkiye'de beş ayrı yerde Tarımsal Araştırma İstasyonu kurulması planlanarak İsviçre'den tarım uzmanı Prof. Dr. Odet Perrin ile anlaşılır. Türkiye'de tohum 1slah araştırmaları 13 Aralık 1925 tarihinde Eskişehir Sazova'da Eskişehir Tohum Islah İstasyonu'nda "Islah-1 Buzr (Büzür) ismi ile başlar. Bu istasyon 1929 yılında ilk kez 1slah edilmiş 5 ton, 1931 yılında 20 ton tohum halka dağıtılır (Emcet Yekta, 1931: 828). Daha sonra Ankara, İstanbul Yeşilköy, Adapazarı ve Erzurum'da ve Samsun'da Tohum ıslah istasyonu açılır (İstatistik Yıllığı, C:19 1951: 268). Bu istasyonlarda ıslah edilen tohumlardan köylüler yaklaşık \% 20-50 arasında daha fazla ürün almasını sağlar (Toprak, 1988: 27).

Adana ve Nazilli'de pamuk sslah istasyonlar1; Adapazarı'nda patates ve misır 1slah istasyonu; Bursa, Diyarbakır, Edirne ve Denizli'de ipek böcekciliği istasyonu, Kayseri'de yonca istasyonu kurulur. Atatürk tarımda tohumun önemini görerek 1930'lu yıllarda Nazilli Araştırma Enstitüsü'nde tohum çalışmalarını başlattı. Daha sonra tohum geliştirmek ve yetiştirmek sorumluluğu Devlet Üretme Çiftlikleri'ne verilir. 
1933 ’te Ankara Yüksek Ziraat Enstitüsü’nün kurulmasıyla başlatılmış, Tarım ve Köyişleri Bakanlığı'nın da katkılarıyla giderek yaygınlaştırılmıştır (Tuncer, 1999; 215).

I. Ziraat Kongresi'nde Tohum Islahı meselesi ayrıntılıca ele alınmıştır. Manisa Milletvekili Yaşar Bey konuyla ilgili bir rapor sunmuştur. Yaşar Bey tohum meselesini “...bir fabrikanın işlemesinde esas nasıl ki iptidai malzeme ise üstü açık bir fabrikaya benzetilen ziraatin de ilk malzemesi muvaffakiyetle amili iyi bir tohumluktur... " diyerek zirai üretim için tohumluğun önemini belirtmiştir (Aydemir, 1999: 318-319,412).

1935 yılında Eskişehir Çifteler Örnek Çiftliği kuru tarımın modernleşmesi, Ankara ve Trakya'da 1938 yılında çiftliklerde buğday tohumlarının ıslahı sağlanmaya çalışılır.

Ülkede kurulan ıslah istasyonları toprağı işlenmesi, ekilmesi, ottan arındırılması, gübre kullanımı, makineli tarım, sulu tarım gibi birçok alanda çiftçilere örnek olmuş ve 1930 ile 1950 arasında ülkede tarım alanında ürünlerin artmasında büyük katkı sağlamıştır. 1923 ile 1938 yılları arasında halkın daha kaliteli ve verimli tohumla daha çok ürün alabilmesi için sekiz adet tohum islah ve deneme istasyonu kurulur (İstatistik Y1llı̆̆1 C:19 1951: 268).

Tohum ıslah istasyonlarından üretilen yeni tohumların iklim, bitki örtüsü, toprak şartlarına göre ülke sathına yayılabilmesi için deneme tarlaları uygulama alanları olmuştur. Ülkede Ordu, Çorum, Erzurum' da örnek deneme tarlaları kurulsa da ülke sathına yaygınlaştırılamamış ve uygulamalar Atatürk Çiftlikleri ile Zirai Kombinalarda gerçekleştirilebilmiştir (İstatistik Yıllığı, C:19 1951: 268).

12 Şubat 1937 yılında 3130 sayılı kanunla Zirai Kombinalar İdaresi kurulur. Kurumun amacı 1slah edilmiş tohum yetiştirip köylüye dağıtmak, modern tarım araçları kullanarak üretim maliyetini düşürmektir (Tekeli-İlkin, 1988: 49).

Çiftliklerin sayıs 1945 'te 13 'e, işledikleri arazi 190 bin hektara ulaşır. Çiftliklerde 1945 'te 147 bin ton buğday ve arpa üretilir. Kombinalarda sürdürülen üretim faaliyetleri ülkenin tahıl ihtiyacının sağlamış, daha iyi araç ve tekniklerle tarımda ürün verimliliğin arttı̆̆ını göstermiştir. 1928-1950 döneminde bu çiftliklerde üretilen buğday hektarda $897 \mathrm{~kg}$ ile ülke ortalamasının \% 28 daha üzerindedir (Mağden, 1949: 49-55; Tezel, 1994: 354, 416).

Pamuk 1slahı ile ilgili ilk girişim 1925 yılında Adana Tohum Islah Komisyonu'nun kurulmasıdır. 1927 yılından itibaren ABD'den 40 pamuk çeşidi getirilerek en uygun pamuk cinsi tespit ve islah çalışmalarına başlanır. 1934 yılında Ziraat Bakanlığı tarafından bir pamuk üretim planı hazırlanarak uygulanmışır. 2582 sayılı yasa 27 Ocak 1936 tarihinde 2903 sayılı Pamuk ıslah Kanunu ile tamamlanır. Buna göre çırçır evleri Ziraat Bakanlığı'nın ihtiyacı olan tohumları piyasa değerinden satmak zorundadır. 1937 yılına kadar Ziraat İşleri Umum Müdürlüğü' nün bir şubesi olarak idare edilen pamuk işleri 4 Haziran 1937 tarihinde kabul edilen 3203 sayılı Ziraat Bakanlığı Teşkilat Kanunu ile doğrudan Bakana bağlı bir müdürlük halini alır (Resmi Gazete, 14 Haziran 1937, Say1: 3630; Tekeli-İlkin, 1988: 51-52). 1940 yılında Adana ve Nazilli'dekine ilaveten Eskişehir Mayıslar ve Malatya'da da birer sslah deneme ve üretme çiftliği oluşturulur. Çukurova'da daha verimli olan klevlant cinsi pamuk yerine akala türü üretilmeye başlanır ve verimli de olur. Doğu Karadeniz Bölgesi için çay ziraatı memlekete ithal edilerek bu bölgede yetiştirilmeye çalışılarak bölge halkının yoksulluktan kurtulmasına uğraşı1ır (Pamuk Encümen Raporu 1931: 693; Kemal 1931: 686).

Tekel eliyle araştırma deneme istasyonlarında tütün tohumu ıslah ve üretme faaliyetleri gerçekleştirilir (Ardıç, 1987: 384). İlk olarak 1927 yılında Ziraat Fen Şubesi açılır, 1931'de tütünle ilgili bir deneme tarlas1 açılır. Ziraat Fen Şubesi 1934 y1lında Maltepe'de Cevizli'de yapılan laboratuvarlar ve yan tesisleri 1936 yılında İnhisarlar İdaresi tarafından Tütün Enstitüsü'ne dönüştürülür. Enstitü Karadeniz tütünün 1slahı için Samsun'da, Efe tütünleri için İzmir (Buca), Şark tütünleri için Malatya'da birer sslah istasyonu açılır. Bu istasyonlarda geliştirilen ürünler için çeşitli yerlerde deneme tarlaları açılır. 1937 yılından sonra istasyonlar fidelikler kurarak üreticiye ücretsiz fide dağıtır. 10 Haziran 1938'de kabul edilen 3437 sayılı Tütün ve Tütün İnhisarı Kanunu ile Tekel bölgesinde en iyi ürünü üretenlere ödül dağıtılır (Tekeli-İlkin, 1988: 59). 
Ülkede Atatürk Dönemi'nde 10 ile 20 hektar arasında değişen elma, incir, zeytin, fındık, narenciye, fıstık, kayısı üzerine çalışan Arifiye, Aydın, İzmir, Giresun, Antalya, Gaziantep ve Malatya meyvecilik istasyonları aç1lır. Kastamonu, Niğde, Ankara, Erzincan, Kütahya, Çanakkale, Alanya, Tarsus ve İzmir'de elma, armut, kayısı, vişne, badem, narenciye, diğer meyve ve süs fidanları yetiştirilmesi amaciyla birere fidanlık kurulur. Ülkede zeytinciliği geliştirmek için İzmir, Muğla, Balıkesir ve Çanakkale'de birere Seyyar Zeytin Bakım Teşkilatı kurulur.

\section{Tarım Makine, Alet ve Edevatı}

Tarımının en önemli yanlarından biri de ilkel şartlarda $\mathrm{m}$ ı yoksa teknolojiden yararlanarak mı gerçekleşmesi hususudur. Artık her kesimde olduğu gibi tarımda da makineleşmeye doğru gidilmesine rağmen bu süreçte çeşitli nedenlerle biraz geri kalınmıştır. 1927'de ülkede ziraat alet ve makineleri miktarı 1441104 adettir. 1920'lerde ülkede traktör az da olsa vardır. Tarıma Cumhuriyetin ilk dört yılında 2000 traktör girmiştir. Ama süreç içerisinde makineli tarıma önem verilerek Devlet Çiftliklerindeki makineleşme ile halka örnek olunmaya ve halkın da makineli tarıma geçmesine çalışılmıştır. 1923-1924 yıllarında 486's1 devlet malı olmak üzere 501 traktörün bulunduğu belirtilmektedir (Silier 1981: 20). 1927 y1lında 1441104 adet ziraat alet ve makinesi yer alır. 1923-1925 yıllarında köylüye 200000 lira değerinde 7677 pulluk dağıtmıştır. Ayrıca yerli pulluk üretimini teşvik için 26 Mart 1931 tarihinde 1797 sayılı Pulluk Kanunu kabul edilmiştir. Bu kanunu uygun olarak ülke içinde pulluk imalatını artırmak için pirimler verilmiş ve yerli imalathanelere faizsiz, uzun vadeli krediler açılmıştır (Resmi Gazete, 2 Nisan 1931).

10 Haziran 1930'da TBMM'den geçen 1710 say11 “Ziraat Makinelerinde Kullanılan Mevadd-1 Müştaile Hakkındaki 752 ve 1527 Sayılı Kanunlara Müzeyyel Kanun” ile tarım makinelerinde kullanılan petrol ve benzin üzerindeki muafiyeti kaldırmıştır. Yasa, petrol ile çalışan traktör kullananların, artık bunları kullanmayacakları için, traktörlerinin tazmin edileceğini de hükme bağlamıştı (Resmi Gazete, 19 Haziran 1930). Bu durumdaki traktör sayısı İktisat Bakanı Şakir Beyin 10 Haziran 1930'da TBMM'de verdiği bilgiye göre 1844 idi (TBMM Zabit Ceridesi, Devre: 3, C: 20, 1930:175).

1923-1938 arası köylülere 200162 liralık pulluk dağıtılır. 1927'de 210000 olan pulluk sayısı (İsmail Hüsrev, 1934: 42) 1936 yılında 410 360'e yükselmiştir (İstatistik Yıllığı, 1940- 1941, 1941: 286). Tarım Bakanlığ 65000 liralık 912 adet kalbur makinesi almış ve bir kısmını uzun vadelerle ödemek şartıyla çiftçilere dağıtmıştır (Gökköl 1935: 258). 1930'lu yılarda çeşitli illere 185 adet dağıtmıştır. 1933 tarihinde traktör, pulluk ve karasaban dışındaki diğer tarım makine ve aletleri şunlardı; 54000 adet her çeşit tırmık, 2 770 tohum ekme makinesi, 4668 orak makinesi, 2235 biçer-bağlar, 728 harman makinesi ve 2947 adet tınaz ve kalbur makinesi (İstatistik Yıllı̆̆ 1940-1941, 1941: 287). 1950 yılına gelindiğinde kültivatör sayısı 10 926, traktör sayıs1 10 926, traktör arabası sayıs1 21 788, traktör mibzer sayıs1 7 244, pancar mibzer sayıs1 519, biçer-döver sayısı 5 618'dir. Yine endüstri bitkilerinin üretimi yapılan bölge ve şehirlerde daha çok makine kullanılmıştır (DİE, 1950).

\section{Atatürk Dönemi'nde Antalya'da Tarım Alanında Devletçilik Uygulamaları}

Antalya coğrafi olarak bir taraftan Akdeniz'e diğer tarafta Toros dağları ile çevrili yaklaşı 20815 km2'lik alana sahiptir (Akbank,1980:12). İl topraklarının \%78'i tarıma elverişli ve bunun içinde ormanlık alanlar (\%74), çayır, mera (\%3) ve bitkisel üretim alanları (\%23) yer alır (TUIK, 2013: 11). İlde dağlı kesim $\% 75, \breve{g}$ 'u, dağlar arasında yer alan platolar \%10,7, yaylalar \%0,5, \%12,9'unu ovalar oluşturur (TUİK: 2013: 12). İlde genel olarak bitki örtüsü makiliktir, iklim bitki üretimi için elverişlidir. İlin coğrafi durumu iç bölgelerle ancak birkaç geçitten ulaşımı sağladığı için ticari faaliyetler yetersiz kalmış ve il kapalı ekonomi yapısını sürdürmüştür.

Osmanlı Devleti'nin son döneminde 1877-1878 Osmanlı Rus Savaşı, Yunanistan'la Girit nedeniyle yapılan savaş, Balkan savaşları nedeniyle Antalya'ya göç eden nüfus kıyı kesimlere devlet tarafindan yerleştirilmiştir. Bu nüfus kıyı bölgelerinde tarım faaliyetlerinde hem getirdikleri tecrübeleriyle hem de bölgenin şartları nedeniyle tarım faaliyetlerinde bulunurlar. Bu göçlerden biri de Antalya'ya 1897 yılında Yunanlılarla yapılan savaş nedeniyle 1899 yılında 5 500- 6000 göçmen kıyı bölgelerinde Antalya ile Alanya 
arasına ovalara yerleştirilir. Bu göçle gelen nüfus daha çok toprakla ilgilendiğinden ovalarda tarım alanları artar. Devlet her aile başına iki odalı bir ev, 100 dönüm arazi, bir çift öküz, alet ve tohum almaları için ailede kişi başına 300 kuruş verir (Baskıcı, 2003: 34).

Antalya'da gerek 1913 tarihli tarım istatistiklerinde ve gerekse 1926-1927 Vilayet Salnamesi verilerine göre bitkisel üretim yapılan yerler arasında en fazla tarlalar, sonra sebze ve meyve bahçeleri, zeytinlikler ve bağlar yer alır. İlde tahıl her yerde yetiştirilmesinin yanında kıyı kesimlerde narenciye, incir, şeftali, zeytin yetiştiriciliği, yerfıstığı, susam ve pamuk ekimi yaygındır. Kıyıdan uzak yerlerde daha çok elma, armut, üzüm yetiştiriciliği, şeker pancarı, baklagiller ve az da olsa tütün ekilir (Yurt Ansiklopedisi,1981: 803).

Ülkede Sıcak İklim Nebatları Teksir ve Islah İstasyonu'nun Güney Anadolu'da yetiştirilecek bitki türlerini tespit ederek uygun yetiştirme metotlarıyla birlikte köylülere sunmak amacıyla İsveç’ten bu konuda uzman olan Dr. T. A. Tengwall ile ülkeden Şevket Bey tarafindan oluşturulur. İstasyon çeltik yanında tropikal ve subtropikal iklim bitkileri ile ilgili araştırmalar başlatır. Burada kahve üretimi denense de uygun ekolojik ortam oluşmaması sonucu istenilen verim alınamamıştır. Bunun üzerine kahve yerine muz denemeleri için Java ve Rodos adalarından muz klonları getirtilerek deneme çalışmalarına başlanır. Esasen Türkiye'ye muz, ilk defa 1870 yılında, süs bitkisi olarak getirilmiş, tarımına ise 1930'larda Alanya'da başlanmıştır.

1930'lu yıllarda Türkiye'nin her türlü tarım ürününü alan Almanlar portakal ve limonla daha fazla ilgiliydiler. Bu nedenle uzun süre portakal ve liman sadece Türkiye'den ithal ederler. Almanya Antalya'da yetişen portakal ve limonu daha fazla talep ederler. Bu nedenden dolayı İktisat ve Ziraat Bakanlıkları hemen Antalya'da narenciye mahsullerinin daha kaliteli yetiştirilmesi için girişimlerde bulunurlar. Bunun sonucunda Antalya'da narenciye numune fidanlığı kurularak yerli fidanların sslahı konusunda bahçıvanların istifadesine sunulmak amaçlanmıştır.

Türkiye'de Atatürk Dönemi'nde başlayan tarım alanındaki devlet uygulamalarının bazı örnekleri Antalya' da da görülür. Bunlardan biri 1lıman iklim bölgesine uygun ürün türlerini belirlemek hedefiyle 1925 yılında Ticaret Bakanı Ali Cemal Bey'in önderliğinde ilk girişim Antalya'da başlar. Ali Cemal Bey narenciyenin bir ülke için çok önemli bir ihraç ürünü oluşturacağını ifade ederek Antalya'da bir fidanlık kurulması talimatı verir. Bunun üzerine 1926 yılında gerçekleştirilen etütlerin neticesinde Tekelioğlu Vakfi'na ait fakat idaresi Antalya Özel İdaresi'ne ait yaklaşık kırk dekarlık bir arazi üzerinde ilk narenciye fidanlığı kurulur. Vilayette narenciye haricindeki tarla bitkileriyle ilgili ilk bilimsel araştırmalar Aksu Bucağı'ndaki tesislerde gerçekleştirilir.

Osmanlı Devleti'nde Antalya ve çevresinde ipek böcekçiliği istasyonu ile sıcak iklim nebatları ıslah istasyonu kurulması amaçlanır. Bu amaç Atatürk döneminde gerçekleştirilir. Vilayette Aksu Bucağı'na da adını veren Aksu çayı kenarında Antalya- Serik yolu üzerinde 1933 yılında "Antalya Çeltik Deneme Tarlası" adı ile bir işletme kurulur. Bu işletme 805 dekar bahçe, 20 dekar fidanlık arazisi ve $12000 \mathrm{~m} 2$ kapalı alana sahiptir. İstasyonda ahırlar ve kümesler de yer alır. İstasyonda hayvancılık alanında da öncü çalışmalar gerçekleştirilir. İstasyonda sekiz tavukhane, dokuz adet büyük ve küçükbaş hayvan ahırı yer alır. Bu ahırlarda tavukçuluk ve hayvancılık alanlarında ıslah, beslenme ve üretim alanlarında araştırmalar yapılır. Damızlık yumurtalardan üretilen civciv ve piliçler Antalya'dan başka Isparta ve Burdur'un da damızlık gereksinimini karşılamaktadır. Tavşancılık, ipekböcekçiliği ve arııılık konusunda da çalışmalar yapılarak elde edilen ürünler halkın yararlanmasına sunulmaktadır (DİE,1940).

Aksu çayı yakınlarındaki fidanlıkta jüt üzerine çalışmalara devam edilir. Enstitünün ana araştırma alanı pamuktur. Bu istasyonda daha sonraki y1llarda buğday, arpa, yulaf, yonca, çeltik, yer fıstığı, susam, hintyă̆ yanı sıra guayul, rami, jüt gibi sıcak iklim bitkileri üzerinde de denemeler gerçekleştirilir. Enstitünün sebzecilik ve hayvancılık şubeleri bulunmaktadır. Zaman içerisinde pamuk üretimi ilde önem kazanınca enstitü yapısında Çırçır ve Sawgon (1960 yılında inşa edilir) fabrikaları ve bunlara hizmete den 18 depo yaptırılarak hizmete alınır.

Antalya topraklarında kolayca yetişebileceği anlaşılan başka bitkiler de vardır. Bunların başında "Guayul kauçuğu" ve "Rami lif bitkisi" gelmektedir. Guayul kauçuğu 1940’larda denemeye alınmış ve bu 
bitkinin Muğla'nın Köyceğiz İlçesi'nden Suriye sınırına kadar uzanan ve Toroslar'ın güneyinde kalan bölgede yetiştirilebileceği anlaşılmıştır, özellikle Antalya'nın kıraç toprakları bu bitkinin yetişmesi için çok uygundur. Sonuçta tarımsal kuruluşlarca İl'de kauçuk ekimine başlanmış ve bir de ham kauçuk işleme fabrikası kurulmuştur. Ancak bu bitki yaygınlaşamamıştır. Rami, lifleri dokumacılıkta kullanılan değerli bir bitkidir. 1950’lerde Antalya Bölge Zirai Araştırma Enstitüsü'nce ilk kez Antalya'da yetiştirilmiş ve iyi sonuç alınmıştır. Ancak bu da, kauçuk gibi, köylü tarafindan benimsenmemiştir.

Bu işletme 1937 yılında Aksu Nahiyesi'ne taşınarak "Sıcak İklim Nebatları Teksir ve Islah İstasyonu" adını alır. Bu işletmeye 1947 yılında "Bölge Tohum Islah ve Deneme istasyonu", 1957 yılında "Bölge Zirai Araştırma Enstitüsü”, 1974 yılında "Pamuk Araştırma Enstitüsü isimleri verilir.

Bu istasyonun bir başka özelliği de yerleşke kültürünün oluşmasına örnek teşkil etmesidir. İşletmenin ana girişi palmiyelerle süslenmiş geniş bir yol aksındandır. Aksın tam karşısında 1938 yılında yapımı tamamlanan iki katlı istasyon binası yer alır. Binanın önünde bir meydan, buraya batı yönünde bağlanan yol üzerinde barınma, eğlenme, dinlenme işlevlerinin yapıldığı sosyal birimler bulunur. Ayrıça işçi lokali, kantin, spor sahası, işçiler için üç farklı türde yapılan lojmanlar ve bir de mescit yer alır. Burada ilk defa sinema ve tiyatro izleme, yemekleri bir arada yeme, baloların düzenlenmesi sosyal alanda kırsal alandaki halka örnek olacak yaşam şekilleridir. Her ne kadar üretim alanlarında kadın çalışan daha az olsa da sosyal birimlerde, ortak kullanım alanlarında kadınlı erkekli ve çocuklarla bir arada olunur.

Başlangıçta sadece erkek işçiler için her odada bir işçinin kalacağı, mutfak, tuvalet ve banyonun ortak olduğu, toplam beş işçinin kalabileceği tarzda lojmanlar yer alırken daha sonra üç odalı, mutfak, banyo ve tuvaletten oluşan aileler için lojmanlara geçilir. Lojmanların odaları doğuya, sslak mekânlar batıya bakacak şekilde ikiz olarak planlanmış ve lojmanların yan ve arka cepheleri boydan boya terastır. İşçiler, teknisyenler ve mühendisler için ayrı lojmanlar yer alır.

Bahçe Kültürleri Araştırma Enstitüsü, Osmanlı Devleti zamanında ülkenin turunçgiller ve diğer meyve gereksinimi Filistin ve Suriye'den karşılanmaktadır. I. Dünya Savaşı'yla bu ülkeler devletin sınırları dışına çıkınca, sınırlı alanlarda yapılan turunçgiller üretimi ihtiyacı karşılayamaz hale gelir. 1936' da turunçgiller yetiştiriciliğini geliştirmek, bahçe sahiplerini bilgilendirmek ve yerli türleri islah için Antalya'da Bahçe Kültürleri Araştırma-Enstitüsü kurulur. Bu kuruluş FAO ile işbirliği yaparak birçok projeler hazırlar ve uygular FAO'nun Yalova Projesi'nden yararlanılarak biri turunçgil meyvelerini değerlendirici, biri de esans üreten iki laboratuvar kurulur. Antalya Bahçe Kültürleri Araştırma Enstitüsü’nde iki meyve paketleme evi çalışmaktadır(Yurt Ansiklopedisi,1981:808)

Antalya'da Burdur- Antalya karayolu üzerinde. Kepez sırtlarından başlayarak kente değin uzanan geniş bir alan Beylerbeyi Murat Paşa tarafindan hicri 982 (miladi 1574) tarihinde vakıf durumuna getirilen 14000 hektarı bulan bu alan uzun yıllar boş kalmıştır. Burada yer yer bataklıklar, yer yer de suların taşıdığı kalkerle yüzeysel kayalar oluşmuştur. Toprakları iyice dinlenmiş ve zenginleşmiştir. 1930'larda Vakıflar Genel Müdürlüğü, kuzeyi ve güneyi kapalı, toprak ve iklim koşulları meyvecilik ve sebzeciliğe çok elverişli olan bu çiftliği işletmeye karar vermiştir.

1939 yilında ziraat hububat üretimi ülkede 7226534 ton, Antalya'da 112735 ton olarak gerçekleşir. Baklagillerin üretimi ülkede 294589 ton, ilde 9966 tondur. Sinai bitkilerin üretimi ülkede 1238975 ton, ilde 19424 ton şeklindedir (DİE, 1940: 157-168).

Tarımının en önemli yanlarından biri de ilkel şartlarda $\mathrm{m} ı$ yoksa teknolojiden yararlanarak mı gerçekleşmesi hususudur. Artık her kesimde olduğu gibi tarım dada makineleşmeye doğru gidilmekte ve bu süreçte çeşitli savaş ve nedenlerle ülkemiz biraz da geri kalmıştır. 1927 Yılında ziraat alet ve makineleri miktarı ülkede 1441104 adet iken ilde 27664 adettir. Ziraat makineleri adeti ülkede 15 384, ilde 325 adettir (DİE,1927).

Ülkede 1947-50 yılları arasında Çiftçiyi Topraklandırma Kanunu gereğince 1497148 m2 arazi 32688 aileye dağıtılmıştır. Antalya'da $49797 \mathrm{~m} 2$ arazi 959 aileye dağıtılır. Savaş yıllarından sonra ülkede top yekun 
kalkınma yoluna gidildiği ve yegane sermayenin çiftçilerin emeğinden geçtiği bilindiği için halkı daha çok çalıştırıp, daha çok ürün elde edebilmek ve feodal yapıyı bozup, demokratikleşme yolunda mesafe alabilmek için böyle bir uygulamaya gidildiği görülmektedir (DİE,1955).

Türkiye'de Atatürk Dönemi'nde tarımda devletçilik alnında çiftlikler, tohum ıslah istasyonları, deneme tarlaları, Ziraat Kombinaları gibi kuruluşlardan Antalya'da da vilayetin iklim ve bitki örtüsüne uygun narenciye, tohum islah istasyonu, muz ve bahçe bitkileri gibi alanlarda kuruluşlar yer almıştır. Bu kuruluşlar büyüklüğü, tarım teknikleri, tohum ıslahı, tohum dağıtımı, tarımda makine kullanımı, sulu tarım, tarımda gübre kullanımı, beraber yaşama kültüründe (çalışma, mesai kavramı, bina, yerleşke, eğlenme) halka örnek olma, yörenin ekilebilir arazisinin ve buradaki ürünün artması gibi birçok alanda halka örnek olmuş ve tarım teşvik edilmiştir. 


\section{Sonuç}

Ülkede başlıca zirai ürünlerinin ekiliş, üretim ve veriminde tahıllar, yumru kökler, sınai bitkileri, sebze ve meyveler önem kazanır. Bu çeşitlerin ekildiği arazi, üretimi ve hektar başına düşen verim artar. Bu dönede tarım alanında geniş piyasa imkanlarının var olmayışı, işletmelerin büyükçe kısmının geçim için üretim yapması sonucunda verimliliği yüksek, sulak, ekime elverişli alanların kullanılmasına doğru eğilim başlar. Dar bir alan ekildiğinden geniş ve zengin meralarda hayvancılığın daha çok gelişir. Hayvansal gübrenin daha çok kullanılması ve karasabandan dolayı toprak fazla aşındırılması ve nadasın daha geleneksel halde olması ziraatın gelişmesini engeller.

1927 yılı nüfus sayımı verilerinde buğday üretimine yer verilir. Buna göre ülkede 2439838 hektar alanda buğday ekilmekte ve 1333150 ton üretim alınmaktadır. Hektar başına üretim yaklaşık 540 kg' dır. Buğday üretimi 1923-1925'yılları ortalaması 972000 ton iken 1936-1940'da 3636000 tona çıkmıştır. Bu verilere göre buğday üretimindeki artış \%274 olmuştur. Aynı tarihlerde sırasıyla 44000 tondan 64000 tona çıkan pamuk üretimindeki artış oranı \%45 düzeyinde gerçekleşmiştir. Tütün üretimi ise dönem başında 45000 tondan dönem sonunda 68000 tona ulaşarak \%51 oranında artmıştır (Tezel, 1994:355). 1939 yılında ülkede hububat üretimi 7226534 tona, baklagil üretimi 294589 tona, sınaî üretim 1238975 tona ulaşır.

Ziraat Bankası, küçük çiftçilere kredi kolaylıkları tanıyarak faiz haddini düşürmekle yararlı hizmetler yapar. Kooperatifçiliğe önem verilir. Tarım Kredi Kooperatifleri kurulur. Ziraat Okulları ve Yüksek Ziraat Enstitüsü açılır. Köylüye yararlı olmak ve yardım sağlamak amacı ile tohum 1slah istasyonları, numune çiftlikleri açılır. Traktör kullanımı teşvik edilerek ucuz alet ve makine dağıtımı yapılır. Atatürk çiftlikler kurarak ve modern yöntemler uygulayarak çiftçilere örnek olur (Akbank, 1980; 171-175).

Atatürk döneminde toprağın daha fazla ekilebilmesi amacıyla köylüye pulluk, düşük faizli traktör ve aksamları, kimyasal gübre dağıtılır. Bu amaçla Zirai Donatım Kurumu kurulur. Ülkede tarım sslah istasyonları kurularak bölge, toprak, iklim ve bitki örtüsüne göre daha iyi verim alınacak tohumlar yetiştirilir. Numune Çiftlikler açılarak köylülere tarım ve hayvancılık alanlarında rehberlik edilir, halka ücretsiz fidan, düşük faizli damızlık hayvan verilir. Hükümet çiftçinin buğday üretimini Toprak Mahsulleri Ofisi ve Ziraat Bankası ile korumaya çalışır. Atatürk kendisine ait çiftlikleri 1937 yılında devlete bağışlar.

Atatürk Dönemi'nde Türkiye'nin tarım alanındaki ekonomik gelişimi için büyük bir kalkınma hamlesi başlatılmıştır. Böylece tarımsal alanda yapılan reform hareketleri ile köylünün refah düzeyi ve üretimi arttırılmış, endüstri bitkileri üretimiyle "tarıma dayalı sanayi" geliştirilmiştir. Cumhuriyet sürecince doğal nedenler dışında ülkede tarım alanında yapılan reform hareketleri sonucunda üretim sürekli artmıştır. Hatta dünya buhranını izleyen 1930-1935 ve II. Dünya Savaşı'nı izleyen 1940-1945 dönemlerinde en yüksek artışları göstermiştir. Tarım alanındaki bu ürün artışı ve gelişmeler ülkedeki feodal düzenin çözülmesine, tarımda makineleşmeye, iktisadi faaliyetlerin artmasına, sermaye birikiminin sağlanmasına, endüstri bitkilerinin ekilmesi ve çoğaltılmasına, sanayileşmensin alt yapısının hazırlanmasına ve ülke kalkınmasının iç kaynaklarla gerçekleşmesine neden olmuştur.

Atatürk Dönemi'nde tarım alanında gerçekleştirilen devletçilik örneklerinden olan tohum ıslah istasyonu örneği Antalya Aksu'da gerçekleştirilmiştir. Antalya'da narenciye, Alanya'da muz üretimi, sulu tarım, makineli tarım, ekilebilir arazi, araziden alınan üründe artış olurken devletçilik örneği köylüye adeta bir okul ve uygulama alanı olur. 


\section{KAYNAKÇA}

Akbank, (1980), Cumhuriyet Dönemi Türkiye Ekonomisi (1923-1978), İstanbul.

Aksoy, Suat, (1971), 100 Soruda Türkiye'de Toprak Meselesi, Gerçek Yayınevi, İstanbul.

Arat, Emin, (1969), Kemalizm, Yurtta Sulh-Cihanda Sulh, Ayyıldız Matbaası, Ankara

Ardıç, Kamuran, (1987), Atatürk'ün Tarım ve Orman Sevgisi ve Tarım Alanındaki Gelişmeler, TTK Basımevi, Ankara.

Aruoba, Çelik, (1982), “Cumhuriyet'in Kuruluş Yıllarında Türkiye'nin Tarımsal Yapısı ve Tarıma Yönelik Politikalar”, Atatürk Dönemi Ekonomi Politikası ve Türkiye'nin Ekonomik Gelişimi, A.Ü. Siyasal Bilgiler Fakültesi ve Türkiye'nin Ekonomi Kurumu, Ankara.

Atatürk, Mustafa Kemal; (1964), Atatürk'ün Tamim Telgraf ve Beyannameleri 1917-1938, Derl: Nimet Arsan, Türk İnkılap Tarihi Enstitüsü Yayınları, Ankara.

Avcıoğlu, Doğan, (1969), Türkiye’nin Düzeni (Dün, Bugün, Yarın), Bilgi Yayınevi, İstanbul.

Ayas, Nevzat,(1948), Türkiye Cumhuriyeti Milli Eğitimi, Milli Eğitim Bakanlığı Yay., Ankara.

Aydemir, Şevket S.,(1999), İkinci Adam, C.I, Remiz Kitapevi,İstanbul.

Aydemir, Şevket S.,(1999b), İkinci Adam, C.II, Remzi Kitapevi, İstanbul.

Aydemir, Şevket S.,(1999c), İkinci Adam, C.III, Remzi Kitapevi, İstanbul.

Aysan, Mustafa, (1987), “Atatürk’ün Ekonomik Görüşü”, Atatürk Yolu, AKDTYK, Atatürk Araştırma Merkezi Yayınları, Ankara.

Baskıcı, Murat,(2003),Osmanlı Topraklarında Makineleşme: 1870-1914, A.Ü., Siyasal Bilgiler Fakültesi, Ankara.

Baysal, Kubilay, (1984), Türkiye Ekonomisi, Nadir Kitapevi, İstanbul.

Biseo, B., (1995), "Türkiye Holstein Friesian (HF) Yetiţtiriciliğinde Hedefler ve Bu Alanda Türk-Almanİtalyan İşbirliği’, Türk Holstein FriesianYetiţtiricileri Dergisi, Y1l: 1, 15 Haziran.

Boratav, Korkut, (1974), 100 Soruda Türkiye'de Devletçilik, Gerçek Yayınları, İstanbul.

Boratav, Korkut, (1997), “İktisat Tarihi 1908-1980”, Çağdaş Türkiye IV, 1908-1980, İstanbul.

Cevdet Nasuhi, (1931), “Zirai Kooperatifçiliğimiz”, 1931 Birinci Ziriat Kongresi İhtisas Raporları, Milli İktisat ve Tasarruf Cemiyeti Yayınları, İstanbul.

Çalgüner, Cemil, (1971), Arazi Mülkiyet Rejimi ve Türkiye'deki Durum, Ankara Üniversitesi Ziraat Fakültesi Yay., Ankara.

Çavdar, Tevfik, (1971), Milli Mücadeleye Başlarken Sayılarla, Vaziyet ve Manzara-i Umumiye, Milliyet

Yayınlar1, İstanbul, Mart.

DİE, (1927), 1927 Y11ı Genel Nüfus Sayımı Verileri.

DİE, (1927), 1927 Y11 Tarım Sayımı Verileri.

DİE, (1935), 1935 Yı1ı Genel Nüfus Sayımı Verileri.

DİE, (1973), Ekonomik ve Toplumsal Gelişmenin 50.Y1lı, Ankara.

DİE, (1993),̇̇l ve Bölge İstatistikleri, Ankara.

DİE, (1940), 1940 Yı1ı Genel Nüfus Sayımı Verileri. 
DİE, (1950), 1950 Ziraat Sayımı Neticeleri.

DİE, (1950), 1950 Yı1ı Genel Nüfus Sayımı Verileri.

DİE, (1955), 1955 Yı1ı Genel Nüfus Sayımı Verileri.

Dinler, Zeynel Abidin, (1993), Bölgesel. İktisat, Ekin Kitapevi, Bursa.

Dura, Cihan, (1991), Türkiye Ekonomisi, Erciyes Üniversitesi Yay., Kayseri.

Düstur, (1922), III. Tertip, C: 3.

Düstur,(1924), 3.Tertip, C.5.

Düstur,(1924), 3.Tertip, C.8.

Düstur,(1927), 3.Tertip, C.18.

Düstur,(1937), 3.Tertip, C.5.

Eldem, Vedat (1970), Eldem, Osmanlı İmparatorluğu'nun İktisadi Şartları Hakkında Bir Tetkik, TTk Basımevi, Ankara.

Emcet Yekta., (1931), 1931Tohum Islahının Vazifeleri. 1. Ziraat Kongresi İhtisas Raporları 1931. Míllî İktisat ve Tasarruf Cemiyeti Ankara

İnalcık, Halil (1990), “Köy, Kôylü ve Imparatorluk,” V. Milletlerarası Türkiye Sosyal ve İktisat Tarihi,

Kongresi. Tebliğler, M.O. Türkiyat Araştırma ve Uygulama Merkezi, İstanbul, 21-25 Ağustos 1989 Ankara: T.T.K Yayını: 1.11

Gençav, Hasan, (1989), “Çaya Gönül Verenler”, Çaykur Dergisi, Sayı: 12.

Gökköl, Mirza,(1935), Türkiye Buğdayları, C: I, T.C. Ziraat Vekâleti Yayınları, İstanbul.

Görgün, Sevim, (1977), “Atatürk Dönemi Maliye Politikası”, Atatürk Döneminde Türkiye Ekonomisi Semineri, İstanbul.

Güran, Tevfik (1992), 'Zirai Politika ve Ziraatta Gelişmeler, 1839-1876,' 150. Yılında Tanzimat, Ankara: TTK Yayını.

İnan, Ayşe Afet, (1982), Türkiye İktisat Kongresi, Türk Tarih Kurumu Yayınlarından, Dizi XVI, Ankara.

İnan, Ayşe Afet, (1988), İzmir İktisat Kongresi (17 Şubat-4 Mart 1923), Atatürk Kültür, Dil ve Tarih Yüksek Kurumu Türk Tarih Kurumu Yay., Ankara.

İsmail Hüsrev,(1934), Türkiye Köy İktisadiyatı, Matbaacılık ve Neşriyat Türk Anonim Şirketi, İstanbul.

İstatistik Umum Müdürlüğü,(1941), İstatistik Y1llığ1 1940-1941, C: 12, Ankara.

İstatistik Genel Müdürlüğ̈̈; (1951), İstatistik Y1llı̆̆1, C:19, Ankara.

Kireyev, Nikolai G., (1987), "SSCB Dışişleri Bakanlığı Tarafindan Yayınlanan Sovyet Arşiv Belgelerinde

Açıklanan Türkiye'de Devletçilik Politikası ve 1920-1930 Yıllarında Sovyet- Türk İlişkileri”, I. Uluslararası Atatürk Sempozyumu 21-23 Eylül, AKDTYK Atatürk Araştırma Merkezi Yayını, Ankara.

Owen, R. (1981), The Mlddle East in the WorldEconomy 1800-1914 (London and New York: Methuen).

Kemal, (1931), "Pamuk”, 1931 Birinci Ziriat Kongresi İhtisas Raporları, Milli İktisat ve Tasarruf Cemiyeti

Yayınları, İstanbul.

Keyder, Çağlar, (1993), Dünya Ekonomisi İçinde Türkiye (1923-1929), Tarih Vakfi Yurt Yayınları, İstanbul. 
Keyder, Çağlar, (1975), Keyder, “Agriculture and the State An Inguiry into Agriculture Differentiation and Political Alliances, the Case of Turkey", Journal of Peasant Studies, Vol. 2, No: 4.

Kongar, Kongar, (1983), Atatürk Üzerine, Remzi Kitapevi, İstanbul.

Lewis, Bernard, (1988), Modern Türkiye'nin Doğuşu, TTK Yayınları, Ankara.

Mağden, Ragıp Ziya, (1949), Zirai Kombinalar, Güney Matbaacılık ve Gazetecilik, Ankara.

Mağden, Ragıp Ziya,(1959), Zirai Öğretimde 110 Yıl, Türk Yüksek Ziraat Mühendisleri Birliği Yay., Ankara.

Mears, E.G., (1924), Modern Turkey, New York, Aktaran Tevfik Çavdar, Milli Mücadeleye Başlarken Sayılarla, Vaziyet ve Manzara-i Umumiye, İstanbul 1971.

Minibaş, Yüksel, (1989), Azgelişmiş Ülkelerde Kalkınmanın Finansman Politikaları ve Türkiye, İstanbul Üniversitesi Yay., İstanbul.

Muhtar, Ahmed, (2015), “Zirai Program, Osman ve Maadin ve Ziraat Nazırı Aristidi Paşa’ya”, Ulum-1

İktisadiyye ve İctimaiyye Mecmuası, C 3, Doğu Kitapevi, İstanbul.

Mülayim, Ziya Gökalp. (1998), Atatürk’ten Bugüne Kooperatifçilik, Ankara, Yetkin Yayınları.

Önsoy, Rıfat (1988), Tanzimat Dönemi Osmanlı Sanayi ve Sanayileşme Politikası, T. İş Bankası Yay., Ankara.

Önder, İzzettin,(1988), “Cumhuriyet Döneminde Tarım Kesimine Uygulanan Vergi Politikası”, Türkiye’de

Tarımsal Yapılar, Der.: Şevket Pamuk, Zafer Toprak, , Yurt Yayınları, Ankara.

Pamuk Encümen Raporu, (1931),1931 Birinci Ziriat Kongresi İhtisas Raporlar1, Milli İktisat ve Tasarruf

Cemiyeti Yayınları, İstanbul.

Pamuk, Şevket (1984), Osmanlı Ekonomisi ve Dünya Kapitalizmi (1820-1913), Yurt Yayınları, Ankara.

Resmi Gazete, 20 Haziran 1933 Say1: 2432

Resmi Gazete, 14 Haziran 1937, Say1: 3630

Resmi Gazete, 19 Haziran 193

Sağlam, Dündar, (1977), Türkiye Ekonomisi, Yapısı ve Temel Sorunları, Kalite Matbaaası, Ankara.

Silier, Oya, (1981), Türkiye'de Tarımsal Yapıların Gelişimi (1923- 1938), Boğaziçi Üniversitesi İdari Bilimler Fakültesi Yayınları, İstanbul.

Shaw, Stanford J. E., Shaw, Kural, (2000), Osmanlı İmparatorluğu ve Modern Türkiye, II, İstanbul.

Tanilli, Server,(1994), Uygarlık Tarihi, Cem Yayınevi, İstanbul.

Tayşi, Vamık, (1940),“Türkiye’de Kuraklık Felaketi ve Onunla Mücadele İmkanları”, Ziraat Dergisi, Sene: 1, Sayı: 1, Ankara.

Tecer, Meral,(2006), “Atatürk Döneminde (1923-1938) Ekonomik Örgütlenme”, Amme İdaresi Dergisi, C: 39, Sayı: 4, Aralık, Ankara.

Tekeli, İlhan-İlkin, Selim, (1988), "Devletçilik Dönemi Tarım Politikaları (Modernleşme Çabaları)", Türkiye'de Tarımsal Yapılar (1923- 2000), Der.: Şevket Pamuk, Zafer Toprak, Yurt Yayınları, İstanbul.

Tezel, Yahya Sezai,(1994), Cumhuriyet Döneminin İktisadi Tarihi: 1923-1950, Üçüncü bask1, Tarih Vakfı Yurt Yayınları, İstanbul. 
Toprak, Zafer, (1988), “Türkiye Tarımı ve Yapısal Gelişmeler 1900- 1950”, Türkiye’de Tarımsal Yapılar (1923-

2000), Der.: Şevket Pamuk, Zafer Toprak, Yurt Yayınları, İstanbul.

Tuncer, Hüner, (1999), “Tarımda Bir 'İlk’in Ardından...” Dr. Hadiye Tuncer'e Armağan, Ankara.

Turan, Kemal,(2000), Türk-Alman Eğitim İlişkilerinin Tarihi Gelişimi, Ayışı̆̆ı Kitapları, İstanbul.

Turan, Şerafettin, (2000), İsmet İnönü, Yaşamı, Dönemi ve Kişiliği, Ankara.

TUIK, (2013), Seçilmiş Göstergelere Göre Antalya.

Türk Parlamento Tarihi IV. Dönem 1931-1935.

TBMM Zabit Ceridesi, (1930), Devre: 3, C: 13, TBMM Matbaas1, Ankara.

TBMM Zabit Ceridesi, (1937), Devre: 3, C: 20, TBMM Matbaas1, Ankara.

Türkiye İktisat Kongresi,(1981), 1923-İzmir, Haberler-Belgeler-Yorumlar, Haz., A. Gündüz Ökçün, Ankara Üniversitesi SBF, Yayınları, Ankara.

Ulus, (1949), 8 Temmuz.

Yurt Ansiklopedisi, (1981), Anadolu Yayınc1lık, İstanbul. 